\title{
Checking into China's cow hotels: Have policies following the milk scandal changed the structure of the dairy sector?
}

\author{
D. Mo, ${ }^{* 1}$ J. Huang, $†$ X. Jia, † H. Luan,† S. Rozelle,‡ and J. Swinnen* \\ *LICOS Centre for Institutions and Economic Performance, University of Leuven (KU Leuven), Leuven 3000, Belgium \\ †Center of Chinese Agricultural Policy, Institute for Geographical Sciences and Natural Resources Research, Chinese Academy of Sciences, \\ Beijing 100101, China \\ ¥Food Security and the Environment Program, Freeman Spogli Institute, Stanford University, Stanford, CA 94305
}

\begin{abstract}
China's milk scandal is well known for causing the nation's largest food safety crisis and for its effect on thousands of children. Less, however, is known about the effect on the other victim: China's small dairy farmers. Although small backyard producers were not the ones that added melamine to the milk supply, the incomes of dairy farmers fell sharply after the crisis. In response, one of the actions taken by the government was to encourage small dairy producers to check into production complexes that were supposed to supply services, new technologies, and provide for easy/bulk procurement of the milk produced by the cows of the farmers. Because both farmers and their cows were living (and working) away from home, in the rest of the paper we call these complexes cow hotels. In this paper we examine the dynamics of China's dairy production structure before and after the milk scandal. In particular, we seek to gain a better understanding about how China's policies have been successful in encouraging farmers to move from the backyard into cow hotels. We also seek to find if larger or smaller farmers respond differently to these policy measures. Using data from a sample of farmers from dairy-producing villages in Greater Beijing, our empirical analysis finds that $1 \mathrm{yr}$ after the milk scandal, the dairy production structure changed substantially. Approximately one quarter (26\%) of the sample checked into cow hotels after the milk scandal, increasing from $2 \%$ before the crisis. Our results also demonstrate that the increase in cow hotel production can largely be attributed to China's dairy policies. Finally, our results suggest that the effects of government policy differ across farm sizes; China's dairy policies are more likely to persuade larger farms to join cow hotels. Apparently, larger farms benefit more when they join cow hotels. Overall, these results suggest that during the first year after the crisis, the government policies
\end{abstract}

Received July 12, 2011.

Accepted December 31, 2011.

${ }^{1}$ Corresponding author: di.mo@econ.kuleuven.be were effective in moving some of the backyard farmers into cow hotels (although 60\% farmers remained backyard producing).

Key words: cow hotel production, China's milk scandal, dairy policies

\section{INTRODUCTION}

China's milk scandal of 2008 struck when it was discovered that milk suppliers (traders and milk collection stations) were adding melamine, a colorless crystalline compound, to artificially boost the protein readings of their milk (Xin and Stone, 2008). In July 2008, the initial reports emerged about child health cases in Gansu Province. Two months later melamine made it for the first time to the headlines of many of China's domestic newspapers when a connection between Sanlu Group's baby formula (Sanlu Group, Shijiazhuang, China) and the Gansu health cases was confirmed by the Ministry of Health. The media-both inside and outside of China - then covered the incident extensively and it was revealed that about 300,000 children became sick (Barboza, 2008). The milk scandal, as we call it in the rest of this paper, was born and before it was over, it affected food supplies in scores of nations and every one of China's provinces (Chen, 2009). Distrusting consumers dramatically reduced demand. Small dairy farmers, who were not the ones that contaminated the milk, had no option but to dump their milk and the income of millions of farm households was negatively affected (The Economist, 2008).

China's government responded on many fronts as the milk scandal unfolded. A series of policies were issued to both reduce the impact on small farmers in the short run as well as to stop the flow of milk through a broken milk marketing system and to create a new system of milk marketing in the place of the broken one. One of the main goals of the government of China in recent years has been to raise the income of rural households (one of the specific objectives of the Ministry of Agriculture is to double the rural income - as of 2008-by the year 2020 with an annual increase of 6\%; Xinhua 
News, 2010). Because of the damages suffered by farmers who were forced to dump their milk and scale back production, an income management policy was rolled out to support the incomes and livelihoods of producers (China News, 2008a).

At the same time, efforts were also made to regulate and restore the marketing chains that had broken down when dairy processing firms were not allowed to buy milk from many of the agents that had been operating in the pre-milk scandal supply chain (State Council of the People's Republic of China, 2008). The overall goal of the marketing management policy was to build a supply chain that was able to deliver safe milk to processing plants. Because it was suspected that a large share of the contamination had occurred in the collection station/middle-of-the-chain marketing firms segment of the supply chain, any milk collection station that failed government inspection was closed down and unqualified buyers were banned from the market (China News, 2008b). After supply chains were purged of many of the suspected suppliers of contaminated milk, the government began to invest in upgrading collection stations to restore the chain (Sohu News, 2008). In the rest of this paper, the set of policies that aimed to create and implement regulations on milk buying and delivery is called China's marketing management policies.

Given the nature and high profile of China's milk scandal and vigor of the government's response, surprisingly little empirical evidence is available to help us understand these policies and their effects on the dairy industry. A wide range of government documents, media reports, and anecdotal studies describe the policies (Hebei Provincial People's Congress, 2009; Chen, 2010). A large number of reports track the fate of those families with children affected by the melamine-laced milk products (First Financial Daily, 2008). However, almost no paper seeks to measure the effects on the dairy producers. One exception is the work of Jia et al. (2011). They use village- and farm-level data from the Greater Beijing Region to econometrically analyze the effect of the government policies on dairy producers. Their analysis demonstrates that, although dairy participation fell and herd sizes decreased after the milk scandal, marketing management policies helped limit the fall of output.

Despite the importance of the paper by Jia et al. (2011) and their findings, no work, to our knowledge, seeks to understand how China's policies affect the structure of production. This in itself is puzzling, given that one of the government's goals of its overall dairy policy was to encourage producers to organize themselves in ways that would allow for both more efficient production and more effective monitoring of quality. Before the milk scandal, China's dairy production was dominated by poor, small-scale farmers with fewer than 5 cows/household (Zhou et al., 2002; Huang et al., 2010). At the time of the emergence of the milk scandal, the small farmer-dominated, fractured structure of China's dairy sector was thought to be (at least in part) at fault for the crisis - either directly or indirectly. Indeed, one of the goals of the marketing management policies was to give incentives to the marketing agents of the supply chain to procure from larger and more reliable dairy farms (Wei, 2008). Subsidies were provided to larger dairy units to install equipment that would aid more efficient and safe marketing. Jia et al. (2011), however, does not seek to understand how China's marketing management policies affected the production structure.

The absence of attention to the impact on the structure of dairy production per se is understandable because marketing management policies (the main focus of the work of Jia et al., 2011) were not designed to directly change the way of raw milk production. When the first marketing management policies were being rolled out, most of China's dairy cows were still in backyards. It was for this reason that China's policy makers designed and implemented another policy that sought to directly change the production structure of China's dairy industry. In the early months after the milk scandal, government officials issued policy directives that ordered local officials to try to convince small, backyard farmers to move their cows into concentrated production complexes (People's Government of Hebei Province, 2008; People's Government of Shanxi Province, 2008; People's Government of Zhejiang Province, 2008, among others). At the time, these complexes (the ones that existed) were both publicly and privately managed (Chen and Zhang, 2010; see Mo et al., 2011 for additional information on cow hotels). The reason (given in the initial policy documents) for the preference for large complexes was to provide dairy farmers with the access to modern production practices and to facilitate better monitoring of the production practices. Ultimately, the policy was designed on the assumption that when dairy cows and dairy farmers were brought to a centralized complex, it would facilitate the production of more sanitary and higher quality milk.

Our primary goal is to study the policy of concentrating the operations of small dairy farmers into the complexes as a way to change the structure of China's dairy industry and upgrade dairy production. These concentrated production complexes (called yangzhi xiaoqu in policy documents) provide us with the important tool to investigate structural changes. Because the creation of the complexes is implemented by requiring dairy farmers to bring their cows from their home and check them into the complexes in the same way people check themselves into guesthouses and lodgings when 
they leave home, we call these complexes cow hotels. The complex could also be called dairy farmer hotel because, in many cases, the complex is so far from a dairy farmer's home village that he/she is unable to go back and forth 2 to 3 times per day to milk, feed, and take care of his/her dairy cows. As a result, the farmer will also check himself/herself into the complex and live there.

A cow hotel is a state- or privately owned dairy cow production and milking complex. Both milk production and collection takes place in a single, centralized location. The cows in the hotel are brought in by several different individual farmers who often will live inside the complex also (in a small dormitory room or standalone hut). A dairy complex is typically managed by a single manager that is in charge of coordinating the breeding, milking, and marketing. The dairy farmers take care of their own cows and are subject to the rules and regulations of the cow hotel. The set of policies that were implemented to facilitate and encourage farmers to join, or check into, cow hotels are, thus, called cow hotel policies.

Although the cow hotel policy documents and efforts of the government to implement the policy are clear, the question remains how effective the policies have been in convincing backyard farmers to join cow hotels. Although there are benefits associated with cow hotel farming, there are obvious costs as well. Media and government reports have mostly focused on the efficiency and welfare gains of the farmers in joining cow hotels (Zhangjiakou News, 2009; The Economic Daily, 2010). Some argue that cow hotel farming could lead to productivity improvement with scale economies and upgraded facilities (Ministry of Agriculture, 2011). Importantly, because farmers are required by their contracts to sell the raw milk to the marketing division of the cow hotel, it could provide better access to the output market (as often with larger-scale production structures) (Swinnen, 2009). However, other anecdotal studies and reports suggest that cow hotels are not always efficient (Chen and Zhang, 2010). In some hotels, inadequate investment is made into the hotel's facilities, technologies, and management; cows may be at higher risk of disease because of the increased herd size. In addition, as farmers need to take care of the cows in the hotel, they incur higher commuting costs (or the psychological costs of living away from home) compared with when their cows are being raised in their own backyards. Using the services of cow hotels also can impose other direct and indirect costs on farmers, as they often live far from their own villages (Farmers' Daily, 2010; Li, 2010).

The goal of our study is to gain a better understanding of which farmers (with what characteristics) are most likely to join cow hotels and whether the cow hotel policy was effective in inducing farmers to check into cow hotels. As the benefits and costs associated with cow hotel farming (introduced above) are likely to differ for farms with different herd sizes, it could be that larger farms enjoy more efficiency gains and less per-unit costs than do smaller farms. Consequently, policies may exhibit heterogeneous effects on large and small farmers' propensity to join cow hotel.

To meet this goal, we have 3 specific objectives. First, we examined the dynamics of China's dairy production structure before and after the milk scandal. Second, we measured how the 2 sets of policies, China's marketing management policy and the cow hotel policy (especially) have influenced dairy farmers to join cow hotels (or have failed to move them out of backyard production). Third, we estimated the heterogeneous effects of the policies on farmers of different herd sizes.

Due to limited funding and organizational resources, we restricted the scope of our study to dairy production structures in the Greater Beijing Region. Although the crisis was national, it is interesting and informative to study the case of Greater Beijing. Beijing was one of the first regions that noticed urinary tract stones in infants (Chen, 2009). The issue was ranked as the top priority on the agenda of the State Council during the first months after the scandal in Beijing. Provincial documents show that similar policies have been designed in Beijing as well as in many other provinces to counter the crisis (Wei, 2008; People's Government of Hebei Province, 2008; People's Government of Shanxi Province, 2008; People's Government of Zhejiang Province, 2008, among others).

\section{China's Dairy Industry and Farms}

Demand and supply of dairy products have changed dramatically during the past 2 decades. In the 1990s, the only major commodity that China's consumers were under-consuming was dairy. The average urban resident in 1992 consumed $9 \mathrm{~kg}$ per capita of dairy products (measured in milk equivalents), only a fraction of the level in many other nations. Since that time, however, dairy demand, especially in urban areas, has exploded (Zhou et al., 2002).

As dairy demand rose, dairy production also increased sharply (Fuller and Du, 2005; Fuller et al., 2006). In the mid-1990s, China's dairy industry produced only 6 to 7 million tonnes (Liu, 2003-2009). From the mid-1990s to the mid-2000s, the growth of dairy production accelerated to almost 20\% annually. Aggregate production rose to more than 35 million tonnes in 2007, a level that ranked China the third in the world after the United States and India. 
By any measure, China's dairy industry heavily depended on small farmers. In the mid-1990s, the average dairy household owned and milked only 3 cows (Zhou et al., 2002). In the mid 2000s, more than 80 percent of the dairy cows were owned by small households scattered across the country (Lu et al., 2009).

\section{China's Milk Scandal and the Government's Response}

A Harvard Business School case study written by $\mathrm{Lu}$ et al. (2009) listed and described the fundamental pressures in the industry that they believe ultimately led firms to begin to use melamine in China's dairy supply chains. The competition began to exert downward pressure on product prices. Lower prices led to falling profit margins. Facing price pressures from above, dairy companies, in turn, began to counter by transferring some of the competitive pressures to milk-collection stations and dairy farmers.

Being at the very upper end of the highly competitive dairy supply chain, there were not too many margins on which either dairy farmers or local buyers/dealers could move on to try to earn higher profits and decrease costs. There was one, however, on which some farmers and buyers/dealers tried to move. Because payment to dairy farmers and local buyers for their milk was largely based on the volume they supplied, adding water would increase their sales volume. In fact, the press reported extensively on cases in which in some places and at some times both dairy farmers and first-tier buyers in China had been found watering down milk to increase their sales volumes. In response, processing firms and their agents changed the rules of procurement. They began to set standards for the milk that they procured from dairy farmers based on the milk's protein content.

To circumvent the testing (which could detect water being added to the milk), some milk suppliers (mostly traders and milk collection stations) began adding melamine to artificially boost the protein readings of their milk (Xin and Stone, 2008; Gale and Hu, 2009). This was possible because the Kjeldahl method was commonly used to test for protein content of milk. This method is unable to detect differences between the true (organic) protein levels in milk from non-protein nitrogen ones (such as melamine).

Two factors suggest that the firms knew that their raw milk was contaminated. First, all the firms themselves were simultaneously facing profit squeezes and pressures to increase production. Second, the quality control system that China's Administration of Quality Supervision, Inspection, and Quarantine (AQSIQ) was in charge of was mainly based on self-regulation. No third parties were in charge of inspecting the quality of China's milk supply. These 2 factors - temptations for higher profits (or the need to avoid falling profits) and low probabilities of getting caught-led to China's 2008 milk scandal.

\section{The Scope of the Scandal and Its Consequences}

The scandal itself is defined by a long sequence of events that began with children being tested positive for kidney stones at abnormally high rates in Gansu, a poor province in western China, and ended with many countries across the globe and every province in China testing dairy products for melamine and banning thousands of products that came out of China's dairy and other food manufacturing firms.

Popular press coverage throughout the end of 2008 and 2009 focused mostly on the civil and criminal consequences of the scandal (Zhongshan News, 2009). In the end, punishments for the 300,000 victims that became sick, the 6 confirmed deaths, and billions of dollars of economic disruption were given out. Two people were executed. Another one was given a suspended death penalty. Five others received from 15 years to life imprisonment. At least 7 government officials, as well as the Director of AQSIQ, were fired or forced to resign.

One aspect of the milk scandal that has been much less reported on and less understood, is the impact that the scandal had on the millions of dairy farmers. After the milk scandal, as might be expected, farmers were hit hard and by several different factors. First, and most directly, as the milk scandal was unfolding, one of the first responses of government regulators was to shut down production in suspected dairy processing firms. This means, of course, that in many cases, there was an immediate impact, as many dairy households could find no one else to procure their milk (or, if they found a buyer, the milk was only procured at a fraction of the cost of production).

Although the shutdown of processing firms by regulators in the immediate aftermath of the milk scandal hurt farmers, this effect paled in comparison to the ultimate cost. With consumer confidence in the quality of all domestically produced dairy products low, consumer demand for dairy products plummeted (NDRC, 2008). Production followed. Nationwide, after growth of production between 2006 and 2007 of more than 3.3 million tonnes (10\% year-on-year growth), production stagnated between 2007 and 2008 and decreased between 2008 and 2009 (China Ministry of Agriculture, 2010).

What was the nature of the fall in production and its impact on dairy-producing communities? Although 
it is difficult using national level data to assess exactly how production decreased and small dairy farmers were affected, we can see several regularities. First, the fall in the number of dairy farmers accelerated. In Tianjin, the number of dairy-producing households decreased between 2007 and 2008 by 5 percent (Liu, 2003-2009). In Liaoning, the number of dairy-producing households decreased by 23 percent. Second, there also was widespread reporting of farmers that were forced to discard their milk, pouring it into landfills, fields, and dry riverbeds (Ministry of Finance, 2008). Finally, a crisis in the dairy sector meant a crisis for many poor communities and the poor farmers inside them. The progress that the government had made over the past several years in raising farm incomes was threatening to be reversed (State Council of Central Committee of the Communist Party of China, 2008, 2009).

\section{Policy Response}

In response to both the consumer and producer crises that were triggered by the milk scandal, the government's top leader, Premier Wen Jiabao, made a public announcement that addressed many dimensions of the crisis. In particular, he committed his government to revamping the policy environment: "... the crisis has revealed the shortcomings of government supervision [and policy] . . . The situation must be rectified immediately" (Lu et al., 2009). For instance, to strengthen the inspection capabilities, China's General AQSIQ issued a statement "Determination of melamine in raw milk and dairy products" (GB/T 22388-2008) on October 7, 2008. This announcement stated that milk inspectors should use 1 of 3 measurement techniques: HPLC, liquid chromatography-tandem mass spectrometry (LC-MS/MS), or GC-MS to test melamine.

One of the main goals of the policy response was to change the production structure of China's dairy industry to make it more modern and more capable to adopt new technologies that could produce high-quality milk (People's Government of Hebei Province, 2008). The target of this policy was focused on increasing the size of dairy farms and decreasing the dependence of the sector on small backyard farms (Chen, 2010).

In fact, the Wen government kept its promise of rapid policy response. As is often associated with China's policy-making environment, when a crisis exists, the government responds and does so in many different dimensions. Although the total list of policy responses is quite long, in the case of the responses directed at producers, they can be divided into 2 main types: marketing management policy and the cow hotel policy. In the rest of this paper, we seek to understand the ef- fectiveness of these policies in changing the production structure of the dairy industry.

\section{MATERIALS AND METHODS}

Data for this study are based on a panel survey that was conducted in 2005 and 2009 in the Greater Beijing area. In 2005, dairy production data at the village (or community) and household levels were collected as part of a larger survey effort (the Greater Beijing Horticulture and Livestock Survey), which investigated the production and marketing of high-value agricultural commodities in the area of Greater Beijing.

In the first year of the survey, 2005, the authors relied on a spatially based sampling strategy to choose the 50 townships and 200 villages from which we would collect information of dairy production at the community level (and which would ultimately be used to choose our dairy households). To sample villages, a geographic information systems (GIS) sampling approach was begun by delineating the Greater Beijing into 5 concentric circles with the geographical center of Beijing (Tian'anmen). The concentric circles were further divided into 10 wedges by drawing 10 spokes $(140 \mathrm{~km}$ in length) from the center (namely Tian'anmen) to the edge of the outermost circle. Each wedge was defined by 2 spokes that created a $36^{\circ}$ angle. The spokes cut every concentric circle into 10 arcs, creating a total of 50 arcs. On every $36^{\circ}$ arc, 1 randomly selected point was marked. The township geographically located linearly closest to the randomly selected point was included in our sample population. In total, 50 townships were randomly selected with the aid of a GIS mapping program. Within each township, 4 villages were then randomly selected to create a sample population of 200 villages.

In each of the sample villages, an enumeration team, led by the authors, conducted a community survey. To do so, the authors interviewed village leaders about the changes in the community's horticultural and livestock (including dairy) economy between 2000 and 2004. During the sit-down questionnaire survey, village leaders recounted the general information of communities and the production of the village's major high-value commodities. In the case that dairy farming was identified, the authors labeled the village as a dairy village and further asked detailed questions (namely, percentage of dairy farmers, average herd size, the distribution of households with different herd size, the distance to the nearest collection station/dairy processing firm, the number of milk stations in local village and in neighborhood villages, among others). The authors eventually identified 25 dairy villages and 175 nondairy villages from among the 200 sample villages. 
After the conclusion of the community survey (and identification of the dairy villages), the first round of our household dairy survey in 2005 was conducted in the 25 dairy villages. To execute the survey, several steps were taken. First, in each village, all households were divided into 2 groups based on whether or not they owned cows. In other words, all households were labeled as a dairy farmer (or dairy household) or nondairy farmer (or nondairy household). Second, we devised a sampling scheme that was used to draw a sample of dairy and nondairy farmers. In villages where the number of dairy farmers was more than 50, 20 farmers were randomly selected-14 dairy households and 6 nondairy households. In the cases of villages in which the number of dairy farmers was higher than 7 but lower than 50, the authors randomly sampled 10 farmers in total -7 dairy farmers and 3 nondairy farmers. When the total number of dairy farmers in a village was lower than 7 , the authors surveyed all of the dairy farmers. The 2005 household survey included 243 farmers in total; $63 \%$ of them were dairy farmers. For some basic production activities, such as participation in dairy farming and herd size, we asked households about both the current year (2005) and a point of time 4 yr earlier (2000).

During the 2005 household survey, in different blocks of the survey, farmers were asked about their individual, household, and dairy characteristics. Enumerators collected information on the age, education level, and employment history of each household member. The value of the household's assets was collected in an attempt to assess each family's wealth. Respondents also provided information on the nature of their dairy activities, including their participation history, distinguishing backyard farming, cow hotel farming, and nondairy activities, their herd size, and location if they were dairy farmers.

In October of 2009 (about 1 yr after the scandal) we organized a second round of the village and household surveys. The idea was to track the evolution of the dairy producers, their activities, and the policies that they faced in the same villages and same households that had been interviewed in 2005 as a way of assessing the impact of the scandal.

To the greatest extent possible, our strategy in the second round was to ask the same respondents the same questions (complemented with questions specific to the milk scandal). To do so, we began with a second round of the community survey. Enumerators asked the village leaders (which in more than half of the villages were the same) the same set of questions as they did in the first round.

The household survey was also repeated. The same information that was collected in 2004 was collected again. In addition, and to be able to more precisely pin down the effect of the milk scandal, we asked farmers to recount their dairy production activities for the year before the crisis in 2008 (pre-scandal dairy activities) and at the time of the survey for 2009 (post-scandal dairy activities). A section was added on their perceptions about the way that the government's post-scandal policies affected their dairy operations.

Finally, in addition to repeating the village and household surveys, we also conducted a survey of the officials that were in charge of dairy policies at the township level (in each of the sample townships). In total, the 25 villages in our sample were located in 15 townships. In these 15 township surveys, we were mainly interested in documenting the exact dates that dairy policy actions were issued from county officials to township leaders that were placed in charge of dairy production in each township. The questions were organized in a way that allowed us to pinpoint the policy efforts and timing of a) the production management policies and b) the marketing management policies. The timing of the policy actions were recorded on a month-by-month basis.

Based on the 2 rounds of survey, we were able to create a panel of townships, villages, and households. We included all 121 dairy households in our sample in August 2008, which referred to a baseline before the scandal. The panel continued with the month end of September in 2008 when the scandal was exposed on the public media and October when a set of national interventions as a prompt response to the crisis was disclosed. The data are then followed by the months January, May, and September in 2009. Therefore, in total, we have 726 observations.

\section{Definition of Variables}

The data described in the preceding section were used to produce information to meet our objective of tracking dairy production before and after the milk scandal. To do so, we created variables tracking dairy production and post-milk scandal policies and their implementation after the scandal. We also created several other variables that might have affected dairy production to be able to improve the estimation efficiency of the effects of the government's policy response.

Dependent Variables: Farm Organization. We used 3 dependent variables to indicate, respectively, whether a farmer had checked himself into a cow hotel, continued to operate as a backyard producer or had dropped out of dairy production. The dummy variable cow hotel producer equaled 1 if, at the end of the time period, the farmer joined a cow hotel, and equaled 0 otherwise. Similarly defined, the dummy variable backyard producer equaled 1 if the farmer continued 
to produce as a backyard farmer at the end of the time period, and equaled 0 otherwise. Finally, the dummy variable exited the dairy sector equaled 1 if the farmers left dairy production between the start and the end of the time period, and equaled 0 otherwise.

Independent Variables of Interest: Policy Variables. We asked township leaders to tell us exactly the initial time (by month) that they were mobilized (by upper-level policy makers) to move backyard dairy operations into cow hotels. The variable cow hotel policy was generated from this information as a dummy variable that equaled 1 if the policy had been implemented and equaled 0 if it had not been implemented.

To create a variable to measure the implementation of the marketing management policy in each sample township, we asked each township leader whether he/ she had ever received a policy document (from the county government) that did any of the following: a) ordering the township to begin inspections of milk procurement stations or b) upgrading milk procurement stations in the townships with promises of subsidies for the stations. The approach that we used to create the variable marketing management policy is similar to the approach that we used to create the variable cow hotel policy. Specifically, marketing management policy is a variable that equaled 1 if the policy had been implemented and 0 if it had not been implemented.

Control Variables. We also used our data to create several control variables. The variable herd size was a household-level variable indicating the number of cows that the household owned before the scandal. It was a number that was greater than or equal to 0 . The variable education equaled the number of years of educational attainment of the head of household. The variable age was measured as the age of the head of household. The variable percentage of off-farm labor was measured by dividing the accumulated days of household members working off-farm over the total working days. To measure household wealth, we collected and aggregated the value of the housing assets, furniture, and other durable consumption assets. Asset value per capita was created by dividing household wealth before the scandal by the total number of household members. Finally, we also created the variable dairy training to indicate whether any member of the household had participated in dairy training before the scandal. The variable equaled 1 if at least 1 member received training and equaled 0 if none of them had any training.

Finally, we created 2 control variables at the community level. The village leader was asked whether any villagers were working in dairy companies before the scandal. Based on this information, we created the variable of villager in dairy company, which equaled 1 if at least 1 villager had been working in a dairy company and 0 if no one had worked in a dairy company before the time of the survey. In addition, we also asked the village leader (the respondent for the community survey form) to tell us the total number of households and the number of dairy farms in the village before the scandal. We created a variable of percentage of dairy households in the village as an indicator for dairy production in the village.

\section{Dairy Production Structures in Greater Beijing Before and After the Milk Scandal}

Our data show that in October 2008, 1 mo after the milk scandal and the initial month of government policies, the proportion of cow hotel producers rose sharply (Table 1). Before the milk scandal (August 2008) and the month when the scandal broke out (September 2008 ), only $2 \%$ of all 121 dairy households were producing in cow hotels. These self-organized types only evolved into the current type of cow hotels after the scandal. One month after the scandal, the cow hotel producers increased to $17 \%$. The flow to cow hotels continued after October, but at a slower rate: 1 yr after the milk scandal, the share of farms in cow hotels was $26 \%$. Consistently, backyard producers decreased from $98 \%$ in August 2008 to only 60\% in September 2009. Some of them moved to cow hotels $(26 \%)$ and others dropped out of dairy production (14\%). Among the producers who dropped out, $90 \%$ of them sold their cows to other farmers and only $10 \%$ decided to slaughter their cows.

Our data also show that once the milk scandal surfaced, government action was taken swiftly across many of our sample areas (Table 2). It is not surprising that no policy action penetrated towns to combat the crisis in August and September 2008, as the scandal had just broken out in September. By the end of October, however, 8 out of 14 townships had received policy directives for the cow hotel policy and had started implementation. In the following months, the cow hotel policy spread to other townships. The directives to move dairy cows into cow hotels were announced in all townships but 1 in our sample by the end of September 2009. The marketing management policy was rolled out as quickly as the cow hotel policy: 9 of the township leaders told us during the survey that they had received policy directives in October 2008. Interestingly, no new townships received this policy in the following months.

Descriptive cross-tabulations that relate the rollout of the policies in the sample townships to cow hotel production show that both of the policies seem to be associated with the increase in cow hotel production (Table 2). In the one township where the leader had not received cow hotel policy directives by the end of September 2009, no cow hotel production was found. 
Table 1. The structure of dairy production in rural villages in the Greater Beijing area before and after the milk scandal (August 2008-September 2009)

\begin{tabular}{lcccc}
\hline Date & $\begin{array}{c}\text { Sample } \\
\text { size }^{1}\end{array}$ & $\begin{array}{c}\text { Backyard } \\
\text { producers }^{2}(\%)\end{array}$ & $\begin{array}{c}\text { Cow hotel } \\
\text { producers }(\%)\end{array}$ & $\begin{array}{c}\text { Exited the dairy } \\
\text { sector }(\%)\end{array}$ \\
\hline Aug. 2008 & 121 & 98 & 2 & 0 \\
Sep. 2008 & 121 & 98 & 2 & 1 \\
Oct. 2008 & 121 & 79 & 17 & 3 \\
Jan. 2009 & 121 & 74 & 20 & 7 \\
May 2009 & 121 & 65 & 24 & 12 \\
Sep. 2009 & 121 & 60 & 26 & 14 \\
\hline
\end{tabular}

${ }^{1}$ The total sample size was 121 , which included all of the households who engaged in dairy production in August 2008.

${ }^{2}$ The figures in this table are all month-end data.

${ }^{3}$ Each row of 3 percentage figures should add up to 100. All farmers (who were in dairy production before the milk scandal) must be in 1 (and only 1 ) of the 3 categories (engaged in backyard production, producing in a cow hotel, or exited from dairy production). Some rows add to 101 or 99 because of rounding.

In the townships that were targeted by the cow hotel policy, an abrupt increase in cow hotel producers was found. The proportion of cow hotel producer increased from $2 \%$ in September 2008 to $18 \%$ in October.

A similar pattern was found for the marketing management policy. Cow hotel production increased much faster in the townships that been covered by the marketing management policy than in the townships that had not been the target of the marketing policies (Table 2). In October 2008, cow hotel producers increased from 1 to $20 \%$ in the townships with the marketing policies; in contrast, no increase occurred in the townships without the policies. Possibly due to the more widespread (albeit more gradual) cow hotel policy (which reached several townships that the marketing management policy did not), in the later months, cow hotel production rose gradually to $9 \%$ by May 2009 and $13 \%$ by September 2009 in the townships without the marketing management policy.
The other evidence from our data is that the trend of cow hotel production was consistent for our sample townships before the policies were implemented (Table 2 ). Although the townships with different dairy production and marketing policies started with slightly different ratios of cow hotel production, the ratios did not change in the 2 mo preceding the policies (Table 2, August and September 2009). In other words, townshiplevel time-varying variables seem to have little effect on cow hotel production, although Table 2 does highlight the importance of including township fixed effects to account for a different starting point in our multivariate analysis.

Table 3, however, shows that the policies seemed to have different effects on producers with different prescandal herd sizes. Given that producers were in areas that were targeted by the cow hotel policy, larger producers appeared to be more likely to join cow hotels (the percentages of cow hotel producers in the group with

Table 2. Townships that received policy directives for the cow hotel policy and marketing management policy and percentage change of cow hotel producers in these townships between August 2008 and September 2009

\begin{tabular}{|c|c|c|c|c|c|c|c|}
\hline \multirow[b]{2}{*}{ Policy variable } & \multirow[b]{2}{*}{$\begin{array}{l}\text { No. of } \\
\text { townships }\end{array}$} & \multicolumn{6}{|c|}{$\begin{array}{l}\text { No. of townships that received the policy } \\
\text { directives in or before the following months }\end{array}$} \\
\hline & & $\begin{array}{l}\text { Aug. } \\
2008\end{array}$ & $\begin{array}{l}\text { Sep. } \\
2008\end{array}$ & $\begin{array}{l}\text { Oct. } \\
2008\end{array}$ & $\begin{array}{l}\text { Jan. } \\
2009\end{array}$ & $\begin{array}{l}\text { May } \\
2009\end{array}$ & $\begin{array}{l}\text { Sep. } \\
2009\end{array}$ \\
\hline Cow hotel policy & 14 & 0 & 0 & 8 & 12 & 13 & 13 \\
\hline \multirow[t]{2}{*}{ Marketing management policy } & 14 & 0 & 0 & 9 & 9 & 9 & 9 \\
\hline & & \multicolumn{6}{|c|}{$\begin{array}{l}\text { Cow hotel producers (\%) in the townships } \\
\text { with or without the policy directives }\end{array}$} \\
\hline Township(s) without cow hotel policy by the end of Sep. 2009 & 1 & 0 & 0 & 0 & 0 & 0 & 0 \\
\hline Township(s) with cow hotel policy by the end of Sep. 2009 & 13 & 2 & 2 & 18 & 24 & 25 & 27 \\
\hline $\begin{array}{l}\text { Township(s) without marketing management } \\
\text { policy by the end of Sep. } 2009\end{array}$ & 5 & 4 & 4 & 4 & 4 & 9 & 13 \\
\hline $\begin{array}{l}\text { Township(s) with marketing management } \\
\text { policy by the end of Sep. } 2009\end{array}$ & 9 & 1 & 1 & 20 & 27 & 28 & 29 \\
\hline
\end{tabular}

${ }^{1}$ The total township size was 14, which included all of the townships that had dairy farmers in August 2008.

${ }^{2}$ The figures in this table are all month-end data. 
Table 3. Percentage of cow hotel producers by township policies in September 2009 and pre-scandal herd size terciles

\begin{tabular}{|c|c|c|c|c|}
\hline \multirow[b]{2}{*}{ Policy variable } & \multirow[b]{2}{*}{$\begin{array}{l}\text { No. of } \\
\text { households }\end{array}$} & \multicolumn{3}{|c|}{$\begin{array}{c}\text { Cow hotel producers (\%) by terciles } \\
\text { of pre-scandal herd size }{ }^{1,2}\end{array}$} \\
\hline & & $\begin{array}{c}\text { Herd } \\
\text { size } \leq 5\end{array}$ & $\begin{array}{l}\text { Herd size } \\
>5 \text { and } \leq 10\end{array}$ & $\begin{array}{c}\text { Herd } \\
\text { size }>10\end{array}$ \\
\hline \multicolumn{5}{|c|}{ Cow hotel policy ${ }^{3}$} \\
\hline No & 7 & & 0 & 0 \\
\hline Yes & 114 & 16 & 24 & 50 \\
\hline \multicolumn{5}{|c|}{ Marketing management policy ${ }^{4}$} \\
\hline No & 23 & 11 & 0 & 33 \\
\hline Yes & 98 & 18 & 28 & 46 \\
\hline \multicolumn{5}{|c|}{${ }^{1}$ The figures in this table are all month-end data. } \\
\hline \multicolumn{5}{|c|}{$\begin{array}{l}{ }^{2} \text { In this table, we look at how farms with different herd sizes have responded to the different policies that have } \\
\text { been implemented in response to the milk scandal. This is done by linking farm size with post-scandal produc- } \\
\text { tion structures (cow hotel, backyard production, and quitting dairy production), given the specific policies to } \\
\text { which farmers were exposed. } \\
{ }^{3} \text { To give a rough comparison between the townships in which the policies were implemented and the ones in } \\
\text { which they were not, the cow hotel policy takes its value in September } 2009 \text { (the last period of our sample). } \\
\text { Therefore, "no" indicates that the township government had not received policy directives by September } 2009 \\
\text { and "yes" indicates that the township government had received policy directives by September } 2009 \text {. }\end{array}$} \\
\hline
\end{tabular}

herd sizes equal to or smaller than 5 , larger than 5 and smaller than 11, and larger than 10 were, respectively, 16,24 , and 50\%). Similarly, the marketing management policy appears to have had a stronger effect on larger producers; the percentages for the 3 groups of herd size were 18,28 , and $46 \%$.

Although the descriptive statistics provide us with interesting evidence of the changes in production structures and how the policies may have contributed to these changes, they are of little help in disentangling the effects of the 2 policies, the effect of the dairy crisis, and other confounding factors. For example, due to the overlap in timing and areas of the 2 policies (and the dairy crisis), it is impossible to satisfactorily attribute the part of increase in cow hotel production to each of the 2 policies without multivariate analysis. Therefore, we included all of the policy variables and the control variables in the multivariate analysis in the next subsection.

\section{Econometric Analysis}

In this subsection we present a comprehensive econometric analysis to examine the effect of government policies on dairy production structures. We first discuss our estimation approach. We then present and discuss the results.

Baseline Specification. In estimating the impact of policies on the structure of dairy production, we used a fixed-effects estimation approach to control for non- time-varying township effects and include a large set of household-level characteristics to improve the efficiency of the analysis.

In particular, in this paper, we estimated the following linear probability model:

$$
\begin{gathered}
E\left[y_{i j t}=1 \mid P_{j t}{ }^{C}, P_{j t}{ }^{M}, \text { Crisis }_{t}, \mathbf{X}_{\mathbf{i j t}}, \text { Trend }_{t}\right]=\delta_{1} P_{j t}{ }^{C} \\
+\delta_{2} P_{j t}{ }^{M}+\beta \text { Crisis }_{t}+\gamma^{\prime} \mathbf{X}_{\mathbf{i j t}}+\mu \text { Trend }_{t}+\lambda_{j},
\end{gathered}
$$

where $y_{i j t}$ is the dependent variable for household $i$ in town $j$ and in month $t$. In the first regression, it is a dummy variable that takes the value of 1 if the household is a cow hotel producer and 0 if the household is not a cow hotel producer. In the second regression, it equals 1 if the household is a backyard producer and equals 0 if it is not a backyard producer. In the third regression, it equals 1 if the household has exited the dairy sector and equals 0 if it still engages in dairy production. The cow hotel policy is represented by $P_{j t}{ }^{C}$ and the marketing management policy is represented by $P_{j t}{ }^{M}$. We also included a variable Crisis, which takes on the value 0 before September 2008, the critical month of the breakout of the milk scandal, and takes on the value 1 after the critical month. The crisis variable was used to capture the effect of crisis on the structure of dairy production. The vector $\mathbf{X}_{\mathrm{ijt}}$ includes a series of control variables such as pre-scandal household and village characteristics (as defined in the previous section). We inserted a time trend Trend ${ }_{t}$, which measures the number of months since August 2008 to capture 
the common trend. We also included township fixed effects $\left(\lambda_{j}\right)$ to take account of the township unobservables that may be correlated with non-time-varying township policies and other factors (which might influence dairy production structures). In the equation, $\delta_{1}, \delta_{2}, \beta, \gamma^{\prime}$, and $\mu$ represent the coefficients we estimated in the regressions.

We chose to use a linear probability model for the estimation for several reasons. First, the linear probability model (the model we used) and a logit (or probit) model (which we did not use), in general, produce similar estimates. The main difference is that the linear probability model is less efficient than limiteddependent variable estimators. However, the linear probability model has the key advantage of having straightforward interpretations of the regression coefficients. In producing estimates from the linear probability models, we computed and used Huber-White heteroskedasticity-robust, clustered (at the individual level) standard errors and allowed efficiency improvement in standard errors.

Alternative Specification (Interaction with Herd Size). As discussed in the introduction, it is possible that the policies affected small and large farms differently. To explore the heterogeneous effects of policies on farms that differed in herd size, we estimated the following alternative specification:

$$
\begin{gathered}
E\left[y_{i j t}=1 \mid P_{j t}{ }^{C}, P_{j t}{ }^{M}, \text { Crisis }_{t}, \mathbf{X}_{\mathbf{i j t}}, \text { Trend }_{t}\right]=\delta_{1} P_{j t}{ }^{C} \\
+\left(P_{j t}{ }^{C} \times \text { Size }_{i j t}\right)+\delta_{2} P_{j t}{ }^{M}+\left(P_{j t}{ }^{M} \times \text { Size }_{i j t}\right) \\
+\beta \text { Crisis }_{t}+\gamma^{\prime} \mathbf{X}_{\mathbf{i j t}}+\mu \text { Trend }_{t}+\lambda_{j}
\end{gathered}
$$

where, in addition to the variables that are included in Equation 1, we also included 2 interaction terms (between pre-scandal herd size and the 2 policy variables: $P_{j t}{ }^{C} \times S i z e_{i j t}$ and $\left.P_{j t}{ }^{M} \times S i z e_{i j t}\right)$.

\section{RESULTS AND DISCUSSION}

Tables 4 to 8 report the estimation results. Tables 4, 5, and 6 report estimates for the coefficients from Equation 1, the basic results. Tables 7 and 8 report them for Equation 2, the heterogeneous analysis. Tables 4 and 7 show the estimation results for the dependent variable, which takes the value of 1 if the household is a producer living/working in a cow hotel. Tables 5 and 8 show the results for the dependent variable, which takes the value of 1 if the household is a backyard producer. Table 6 shows the results for the dependent variable, which equals 1 if the household has exited dairy production at some point in time between the outbreak of the milk scandal and the survey. Due to the closeness of the timing of the scandal and the implementation of the 2 policies, we included different combinations of the 3 variables of interest in each set of regressions (for the same dependent variable) to check the robustness of our estimates.

\section{Effect of the Policies on the Structure of Production}

Our results show that the cow hotel policy, which sought to mobilize backyard producers to check into cow hotels, in fact, increased the probability of farmers to join a cow hotel (Table 4). The size of the coefficient suggests that the policy efforts of the government increased the probability of dairy producers being in a cow hotel by $11 \%$ (column 10, row 1). Interestingly, the marketing management policy, which regulates milk buying and delivery, increased the cow hotel production even more, by $23 \%$ (Table 4 , column 10, row 2). The estimates are robust and highly significant across all specifications. The only exception is in the regressions where we included both sets of policy variables - the variable measuring the cow hotel policy and the variable measuring the marketing management policy. When including both policy variables, the coefficients changed slightly with different combinations of these variables in the regressions (Table 4, row 1 and 2).

Our results also demonstrate that the cow hotel policy reduced backyard production by $10 \%$ (Table 5 , column 10, row 1 ). The coefficient is robust across the 10 specifications (Table 5, row 1 ). However, the marketing management policy did not seem to affect backyard production (Table 5, column 10, row 2). The coefficient of this policy varied when we included or excluded the variable of dairy crisis. This almost certainly indicates a high level of correlation between these 2 variables. In this specification, the coefficient on the marketing management policy variable is almost 0 . If this measures the true effect, it means that the marketing management policy has not been effective in reducing backyard dairy production.

Finally, consistent with the findings of Jia et al. (2011), the marketing management policy decreased the probability of dairy farmers to exit dairy sector (Table 6). The size of the coefficient reveals that the policy reduced the decline in the household's participation in dairy production by $23 \%$ (column 10 , row 2 ). The magnitude in Jia et al. (2011) was similar (their estimation was $27 \%$ ). In contrast, the cow hotel policy did not exhibit any effect on quitting dairy production. However, a lot of variation existed in the sign of the variable and its robustness across specifications (Table 6 , row 1$)$. 
Table 4. Results of multivariate analysis estimating the effect of cow hotel and marketing management policies on cow hotel production in Greater Beijing from August 2008 to September 2009 (ordinary least squares with township fixed effects) $)^{1}$

\begin{tabular}{|c|c|c|c|c|c|c|c|c|c|c|c|}
\hline \multirow{2}{*}{$\begin{array}{l}\text { Independent } \\
\text { variable no. }\end{array}$} & \multirow{2}{*}{$\begin{array}{l}\text { Independent } \\
\text { variable }\end{array}$} & \multicolumn{10}{|c|}{ Dependent variable: Cow hotel producer $(1=$ yes; $2=$ no $)$} \\
\hline & & 1 & 2 & 3 & 4 & 5 & 6 & 7 & 8 & 9 & 10 \\
\hline 1 & Cow hotel policy $($ yes $=1 ;$ no $=0$ ) & & $\begin{array}{l}0.16^{* * *} \\
{[4.50]}\end{array}$ & & $\begin{array}{l}0.09^{* * *} \\
{[3.18]}\end{array}$ & $\begin{array}{l}0.11 * * * \\
{[3.27]}\end{array}$ & & $\begin{array}{l}0.16^{* * *} \\
{[4.47]}\end{array}$ & & $\begin{array}{l}0.09 * * * \\
{[3.16]}\end{array}$ & $\begin{array}{l}0.11^{* * *} \\
{[3.25]}\end{array}$ \\
\hline 2 & $\begin{array}{l}\text { Marketing management } \\
\text { policy }(\text { yes }=1 ; \text { no }=0)\end{array}$ & & & $\begin{array}{l}0.20^{* * *} \\
{[4.86]}\end{array}$ & $\begin{array}{l}0.17^{* * *} \\
{[4.55]}\end{array}$ & {$\left[0.23^{* * *}\right.$} & & & $\begin{array}{l}0.20 * * * \\
{[4.83]}\end{array}$ & $\begin{array}{l}0.17^{* * *} \\
{[4.53]}\end{array}$ & $\begin{array}{l}0.23^{* * *} \\
{[4.52]}\end{array}$ \\
\hline 3 & Herd size & & & & & & $\begin{array}{c}0.00 \\
{[1.28]}\end{array}$ & $\begin{array}{c}0.00 \\
{[1.28]}\end{array}$ & $\begin{array}{c}0.00 \\
{[1.28]}\end{array}$ & $\begin{array}{c}0.00 \\
{[1.28}\end{array}$ & $\begin{array}{c}0.00 \\
{[1.28]}\end{array}$ \\
\hline 4 & $\begin{array}{l}\text { Dairy crisis }(1=\text { months after } \\
\text { Sept. } 2008 ; 0=\text { months before })\end{array}$ & $\begin{array}{l}0.16^{* * *} \\
{[4.69]}\end{array}$ & & & & $\begin{array}{l}-0.09^{* *} \\
{[-2.44]}\end{array}$ & $\begin{array}{l}0.16^{* * *} \\
{[4.66]}\end{array}$ & & & & $\begin{array}{l}-0.09^{* *} \\
{[-2.43]}\end{array}$ \\
\hline 5 & Education (yr) & & & & & & $\begin{array}{c}0.00 \\
{[0.16]}\end{array}$ & $\begin{array}{c}0.00 \\
{[0.16]}\end{array}$ & $\begin{array}{c}0.00 \\
{[0.16]}\end{array}$ & $\begin{array}{c}0.00 \\
{[0.16]}\end{array}$ & $\begin{array}{c}0.00 \\
0.16]\end{array}$ \\
\hline 6 & Age (yr) & & & & & & {$\left[-0.00^{* *}\right.$} & $-0.00^{* *}$ & $\begin{array}{l}-0.00^{* *} \\
{[-2.00]}\end{array}$ & $\begin{array}{l}-0.00^{* *} \\
{[-2.00]}\end{array}$ & $\begin{array}{l}-0.00^{* *} \\
{[-2.00]}\end{array}$ \\
\hline 7 & Percentage of off-farm labor & & & & & & $\begin{array}{l}-0.21^{* *} \\
{[-2.53]}\end{array}$ & $\begin{array}{l}-0.21^{* *} \\
{[-2.53]}\end{array}$ & $\begin{array}{l}-0.21^{* *} \\
{[-2.53]}\end{array}$ & $\begin{array}{l}-0.21^{* *} \\
{[-2.53]}\end{array}$ & $\begin{array}{l}-0.21^{* *} \\
{[-2.52]}\end{array}$ \\
\hline 8 & Asset value per capita (1,000 yuan) & & & & & & $\begin{array}{l}-0.04^{* * *} \\
{[-3.15]}\end{array}$ & $\begin{array}{l}-0.04^{* * *} \\
{[-3.15]}\end{array}$ & $\begin{array}{l}-0.04^{* * *} \\
{[-3.15]}\end{array}$ & $\begin{array}{l}-0.04^{* * * *} \\
{[-3.15]}\end{array}$ & $\begin{array}{l}-0.04^{* * *} \\
{[-3.15]}\end{array}$ \\
\hline 9 & Dairy training & & & & & & $\begin{array}{c}0.08 \\
{[1.55]}\end{array}$ & $\begin{array}{c}0.08 \\
{[1.55]}\end{array}$ & $\begin{array}{c}0.08 \\
{[1.55]}\end{array}$ & $\begin{array}{c}0.08 \\
{[1.55]}\end{array}$ & $\begin{array}{c}0.08 \\
{[1.55]}\end{array}$ \\
\hline 10 & Villagers in dairy company & & & & & & $\begin{array}{l}-0.05 \\
{[-0.33]}\end{array}$ & $\begin{array}{l}-0.05 \\
{[-0.33]}\end{array}$ & $\begin{array}{l}-0.05 \\
{[-0.33]}\end{array}$ & $\begin{array}{l}-0.05 \\
{[-0.33]}\end{array}$ & $\begin{array}{l}-0.05 \\
{[-0.33]}\end{array}$ \\
\hline 11 & $\begin{array}{l}\text { Percentage of dairy } \\
\text { households in the village }\end{array}$ & & & & & & $\begin{array}{c}0.01 \\
{[1.19]}\end{array}$ & $\begin{array}{c}0.01 \\
{[1.19]}\end{array}$ & $\begin{array}{c}0.01 \\
{[1.19]}\end{array}$ & $\begin{array}{c}0.01 \\
{[1.19]}\end{array}$ & $\begin{array}{c}0.01 \\
{[1.19]}\end{array}$ \\
\hline 12 & Time trend & Yes & Yes & Yes & Yes & Yes & Yes & Yes & Yes & Yes & Yes \\
\hline 13 & Township effects & Yes & Yes & Yes & Yes & Yes & Yes & Yes & Yes & Yes & Yes \\
\hline 14 & $\mathrm{n}$ & 726 & 726 & 726 & 726 & 726 & 726 & 726 & 726 & 726 & 726 \\
\hline 15 & $\mathrm{R}^{2}$ & 0.32 & 0.32 & 0.33 & 0.34 & 0.34 & 0.39 & 0.39 & 0.41 & 0.41 & 0.41 \\
\hline
\end{tabular}

${ }^{1}$ T-statistics are in brackets. The regression model that includes variables that measure both the cow hotel policy and the marketing management policy (as well as a full set of control variables) is shown in the last column of the table.

$* * P<0.05 ; * * * P<0.01$ 
Table 5. Results of multivariate analysis estimating the effect of cow hotel and marketing management policies on backyard production in Greater Beijing from August 2008 to September 2009 (ordinary least squares with township fixed effects)

\begin{tabular}{|c|c|c|c|c|c|c|c|c|c|c|c|}
\hline \multirow{2}{*}{$\begin{array}{l}\text { Independent } \\
\text { variable no. }\end{array}$} & \multirow{2}{*}{$\begin{array}{l}\text { Independent } \\
\text { variable }\end{array}$} & \multicolumn{10}{|c|}{ Dependent variable: Backyard producer $(1=$ yes; $2=$ no $)$} \\
\hline & & 1 & 2 & 3 & 4 & 5 & 6 & 7 & 8 & 9 & 10 \\
\hline 1 & $\begin{array}{l}\text { Cow hotel policy (yes } \\
=1 ; \text { no }=0 \text { ) }\end{array}$ & & $\begin{array}{l}-0.18^{* * *} \\
{[-4.20]}\end{array}$ & & $\begin{array}{l}-0.14 * * * \\
{[-3.32]}\end{array}$ & $\begin{array}{l}-0.10^{* *} \\
{[-2.28]}\end{array}$ & & $\begin{array}{l}-0.18^{* * *} \\
{[-4.18]}\end{array}$ & & $\begin{array}{l}-0.14^{* * *} \\
{[-3.30]}\end{array}$ & $\begin{array}{l}-0.10^{* *} \\
{[-2.27]}\end{array}$ \\
\hline 2 & $\begin{array}{l}\text { Marketing management } \\
\text { policy }(\text { yes }=1 ; \text { no }=0)\end{array}$ & & & $\begin{array}{l}-0.15^{* * *} \\
{[-3.21]}\end{array}$ & $\begin{array}{l}-0.09^{* *} \\
{[-2.09]}\end{array}$ & {$\left[\begin{array}{c}0.00 \\
-0.04]\end{array}\right.$} & & & $\begin{array}{l}-0.15^{* * *} \\
{[-3.19]}\end{array}$ & $\begin{array}{l}-0.09^{* *} \\
{[-2.08]}\end{array}$ & $\begin{array}{l}-0.00 \\
{[-0.04]}\end{array}$ \\
\hline 3 & Herd size & & & & & & $\begin{array}{l}-0.00 \\
{[-0.08]}\end{array}$ & $\begin{array}{l}-0.00 \\
{[-0.08]}\end{array}$ & $\begin{array}{l}-0.00 \\
{[-0.08]}\end{array}$ & $\begin{array}{l}-0.00 \\
{[-0.08]}\end{array}$ & $\begin{array}{l}-0.00 \\
{[-0.08]}\end{array}$ \\
\hline 4 & $\begin{array}{l}\text { Dairy crisis }(1=\text { months after } \\
\text { Sept. } 2008 ; 0=\text { months before })\end{array}$ & $\begin{array}{l}-0.18^{* * *} \\
{[-4.76]}\end{array}$ & & & & $\begin{array}{c}-0.12 \\
{[-1.64]}\end{array}$ & $\begin{array}{l}-0.18^{* * *} \\
{[-4.74]}\end{array}$ & & & & $\begin{array}{l}-0.12 \\
{[-1.63]}\end{array}$ \\
\hline 5 & Education (yr) & & & & & & $\begin{array}{c}0.02^{*} \\
{[1.75]}\end{array}$ & $\begin{array}{l}0.02^{*} \\
{[1.75]}\end{array}$ & $\begin{array}{l}0.02^{*} \\
{[1.75]}\end{array}$ & $\begin{array}{c}0.02^{*} \\
{[1.75]}\end{array}$ & $\begin{array}{l}0.02^{*} \\
{[1.75]}\end{array}$ \\
\hline 6 & Age (yr) & & & & & & $\begin{array}{l}0.01^{* *} \\
{[2.52]}\end{array}$ & $\begin{array}{l}0.01^{* *} \\
{[2.52]}\end{array}$ & $\begin{array}{l}0.01^{* *} \\
{[2.52]}\end{array}$ & $\begin{array}{l}0.01^{* *} \\
{[2.52]}\end{array}$ & $\begin{array}{l}0.01^{* *} \\
{[2.52]}\end{array}$ \\
\hline 7 & Percentage of off-farm labor & & & & & & $\begin{array}{c}0.08 \\
{[0.67]}\end{array}$ & $\begin{array}{l}0.08 \\
{[0.67]}\end{array}$ & $\begin{array}{l}0.08 \\
{[0.67]}\end{array}$ & $\begin{array}{l}0.08 \\
{[0.67]}\end{array}$ & $\begin{array}{l}0.08 \\
{[0.67]}\end{array}$ \\
\hline 8 & $\begin{array}{l}\text { Asset value per capita } \\
(1,000 \text { yuan) }\end{array}$ & & & & & & $\begin{array}{l}0.04^{* * *} \\
{[3.17]}\end{array}$ & $\begin{array}{l}0.04^{* * *} \\
{[3.17]}\end{array}$ & $\begin{array}{l}0.04^{* * *} \\
{[3.17]}\end{array}$ & $\begin{array}{l}0.04^{* * *} \\
{[3.17]}\end{array}$ & $\begin{array}{l}0.04^{* * *} \\
{[3.16]}\end{array}$ \\
\hline 9 & Dairy training & & & & & & -0.06 & $\begin{array}{l}-0.06 \\
{[-1.19]}\end{array}$ & $\begin{array}{l}-0.06 \\
{[-1.19]}\end{array}$ & $\begin{array}{l}-0.06 \\
{[-1.19]}\end{array}$ & -0.06 \\
\hline 10 & Villagers in dairy company & & & & & & $\begin{array}{l}-0.05 \\
{[-0.27]}\end{array}$ & $\begin{array}{l}-0.05 \\
{[-0.27]}\end{array}$ & $\begin{array}{l}-0.05 \\
{[-0.27]}\end{array}$ & $\begin{array}{l}-0.05 \\
{[-0.27]}\end{array}$ & $\begin{array}{l}-0.05 \\
{[-0.27]}\end{array}$ \\
\hline 11 & $\begin{array}{l}\text { Percentage of dairy } \\
\text { households in the village }\end{array}$ & & & & & & $\begin{array}{l}-0.00 \\
{[-0.64]}\end{array}$ & {$[-0.00$} & $\begin{array}{l}-0.00 \\
{[-0.64]}\end{array}$ & {$[-0.00$} & $\begin{array}{l}-0.00 \\
{[-0.64]}\end{array}$ \\
\hline 12 & Time trend & Yes & Yes & Yes & Yes & Yes & Yes & Yes & Yes & Yes & Yes \\
\hline 13 & Township effects & Yes & Yes & Yes & Yes & Yes & Yes & Yes & Yes & Yes & Yes \\
\hline 14 & $\mathrm{n}$ & 726 & 726 & 726 & 726 & 726 & 726 & 726 & 726 & 726 & 726 \\
\hline 15 & $\mathrm{R}^{2}$ & 0.29 & 0.29 & 0.29 & 0.29 & 0.30 & 0.35 & 0.35 & 0.35 & 0.35 & 0.36 \\
\hline
\end{tabular}

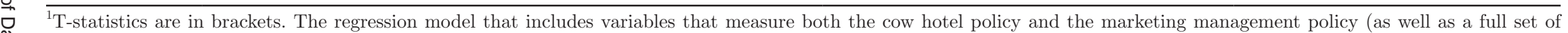
N. control variables) is shown in the last column of the table.

œ $\quad * P<0.10 ;{ }^{* *} P<0.05 ;{ }^{* * *} P<0.01$. 
Table 6. Results of multivariate analysis estimating the effect of cow hotel and marketing management policies on quitting dairy production in Greater Beijing from August 2008 to September 2009 (ordinary least squares with township fixed effects)

\begin{tabular}{|c|c|c|c|c|c|c|c|c|c|c|c|}
\hline \multirow{2}{*}{$\begin{array}{l}\text { Independent } \\
\text { variable no. }\end{array}$} & \multirow{2}{*}{$\begin{array}{l}\text { Independent } \\
\text { variable }\end{array}$} & \multicolumn{10}{|c|}{ Dependent variable: Quitting dairy production $(1=$ yes; $2=$ no $)$} \\
\hline & & 1 & 2 & 3 & 4 & 5 & 6 & 7 & 8 & 9 & 10 \\
\hline 1 & Cow hotel policy $($ yes $=1 ;$ no $=0)$ & & $\begin{array}{c}0.02 \\
{[0.83]}\end{array}$ & & $\begin{array}{c}0.05 \\
{[1.31]}\end{array}$ & $\begin{array}{l}-0.01 \\
{[-0.32]}\end{array}$ & & $\begin{array}{c}0.02 \\
{[0.74]}\end{array}$ & & $\begin{array}{c}0.05 \\
{[1.54]}\end{array}$ & $\begin{array}{l}-0.01 \\
{[-0.34]}\end{array}$ \\
\hline 2 & $\begin{array}{l}\text { Marketing management } \\
\text { policy }(\text { yes }=1 ; \text { no }=0)\end{array}$ & & & $\begin{array}{l}-0.05 \\
{[-1.55]}\end{array}$ & $\begin{array}{l}-0.08 \\
{[-1.58]}\end{array}$ & $\begin{array}{l}-0.23^{* * *} \\
{[-6.78]}\end{array}$ & & & $\begin{array}{l}-0.05^{* *} \\
{[-2.26]}\end{array}$ & $-0.08^{* *}$ & $\begin{array}{l}-0.23^{* * *} \\
{[-2.99]}\end{array}$ \\
\hline 3 & Herd size & & & & & & $\begin{array}{l}-0.00^{* *} \\
{[-2.34]}\end{array}$ & $\begin{array}{l}-0.00^{* *} \\
{[-2.34]}\end{array}$ & $\begin{array}{l}-0.00^{* *} \\
{[-2.34]}\end{array}$ & $\begin{array}{l}-0.00^{* *} \\
{[-2.34]}\end{array}$ & {$\left[-0.00^{* *}\right.$} \\
\hline 4 & $\begin{array}{l}\text { Dairy crisis }(1=\text { months after } \\
\text { Sept. } 2008 ; 0=\text { months before })\end{array}$ & $\begin{array}{c}0.02 \\
{[1.27]}\end{array}$ & & & & $\begin{array}{l}0.21^{* * *} \\
{[4.86]}\end{array}$ & $\begin{array}{c}0.02 \\
{[1.07]}\end{array}$ & & & & $\begin{array}{l}0.21^{* * *} \\
{[2.89]}\end{array}$ \\
\hline 5 & Education (yr) & & & & & & $\begin{array}{l}-0.02^{* *} \\
{[-2.40]}\end{array}$ & $\begin{array}{l}-0.02^{* *} \\
{[-2.40]}\end{array}$ & $\begin{array}{l}-0.02^{* *} \\
{[-2.40]}\end{array}$ & $\begin{array}{l}-0.02^{* *} \\
{[-2.40]}\end{array}$ & $\begin{array}{l}-0.02^{* *} \\
{[-2.40]}\end{array}$ \\
\hline 6 & Age (yr) & & & & & & $\begin{array}{l}-0.00 \\
{[-1.32]}\end{array}$ & $\begin{array}{l}-0.00 \\
{[-1.32]}\end{array}$ & $\begin{array}{l}-0.00 \\
{[-1.32]}\end{array}$ & $\begin{array}{l}-0.00 \\
{[-1.32]}\end{array}$ & $\begin{array}{l}-0.00 \\
{[-1.32]}\end{array}$ \\
\hline 7 & Percentage of off-farm labor & & & & & & 0.13 & $\begin{array}{c}0.13 \\
{[1.41]}\end{array}$ & $\begin{array}{c}0.13 \\
{[1.41]}\end{array}$ & 0.13 & $\begin{array}{c}0.13 \\
{[1.41]}\end{array}$ \\
\hline 8 & Asset value per capita (1,000 yuan) & & & & & & $\begin{array}{l}-0.01 \\
{[-0.91]}\end{array}$ & -0.01 & $\begin{array}{l}-0.01 \\
{[-0.91]}\end{array}$ & $\begin{array}{l}-0.01 \\
{[-0.90]}\end{array}$ & $\begin{array}{l}-0.01 \\
{[-0.90]}\end{array}$ \\
\hline 9 & Dairy training & & & & & & $\begin{array}{l}-0.01 \\
{[-0.39]}\end{array}$ & $\begin{array}{l}-0.01 \\
{[-0.39]}\end{array}$ & $\begin{array}{l}-0.01 \\
{[-0.39]}\end{array}$ & $\begin{array}{l}-0.01 \\
{[-0.39]}\end{array}$ & $\begin{array}{l}-0.01 \\
{[-0.39]}\end{array}$ \\
\hline 10 & Villagers in dairy company & & & & & & $\begin{array}{c}0.10 \\
{[1.27]}\end{array}$ & $\begin{array}{c}0.10 \\
{[1.27]}\end{array}$ & $\begin{array}{c}0.10 \\
{[1.27]}\end{array}$ & $\begin{array}{c}0.10 \\
{[1.27]}\end{array}$ & $\begin{array}{c}0.10 \\
{[1.27]}\end{array}$ \\
\hline 11 & $\begin{array}{l}\text { Percentage of dairy } \\
\text { households in the village }\end{array}$ & & & & & & $\begin{array}{l}-0.00 \\
{[-0.95]}\end{array}$ & $\begin{array}{l}-0.00 \\
{[-0.95]}\end{array}$ & $\begin{array}{l}-0.00 \\
{[-0.95]}\end{array}$ & $\begin{array}{l}-0.00 \\
{[-0.95]}\end{array}$ & $\begin{array}{l}-0.00 \\
{[-0.95]}\end{array}$ \\
\hline 12 & Time trend & Yes & Yes & Yes & Yes & Yes & Yes & Yes & Yes & Yes & Yes \\
\hline 13 & Township effects & Yes & Yes & Yes & Yes & Yes & Yes & Yes & Yes & Yes & Yes \\
\hline 14 & $\mathrm{n}$ & 726 & 726 & 726 & 726 & 726 & 726 & 726 & 726 & 726 & 726 \\
\hline 15 & $\mathrm{R}^{2}$ & 0.13 & 0.13 & 0.13 & 0.14 & 0.16 & 0.19 & 0.19 & 0.19 & 0.20 & 0.22 \\
\hline
\end{tabular}

${ }^{1}$ T-statistics are in brackets. The regression model that includes variables that measure both the cow hotel policy and the marketing management policy (as well as a full set of control variables) is shown in the last column of the table.

** $P<0.05 ; * * * P<0.01$ 
Table 7. Results of multivariate analysis estimating the heterogeneous effects of cow hotel and marketing management policies on cow hotel production in Greater Beijing from August 2008 to September 2009 (ordinary least squares with township fixed effects)

\begin{tabular}{|c|c|c|c|c|c|c|c|}
\hline \multirow[b]{2}{*}{$\begin{array}{l}\text { Independent } \\
\text { variable no. }\end{array}$} & \multirow{2}{*}{$\begin{array}{l}\text { Independent } \\
\text { variable }\end{array}$} & \multicolumn{6}{|c|}{ Dependent variable: Cow hotel producer $(1=$ yes; $2=$ no $)$} \\
\hline & & 1 & 2 & 3 & 4 & 5 & 6 \\
\hline 1 & Cow hotel policy $($ yes $=1 ;$ no $=0)$ & $\begin{array}{l}0.15^{* * *} \\
{[2.97]}\end{array}$ & $\begin{array}{c}0.07^{*} \\
{[1.66]}\end{array}$ & & & $\begin{array}{l}0.08^{* *} \\
{[2.54]}\end{array}$ & $\begin{array}{l}0.11^{* * *} \\
{[3.02]}\end{array}$ \\
\hline 2 & Cow hotel policy $\times$ herd size & $\begin{array}{l}0.00 \\
{[0.53]}\end{array}$ & $\begin{array}{l}0.00 \\
{[0.49]}\end{array}$ & & & $\begin{array}{c}0.00 \\
{[0.47]}\end{array}$ & $\begin{array}{c}0.00 \\
{[0.70]}\end{array}$ \\
\hline 3 & Marketing management policy $($ yes $=1 ;$ no $=0)$ & & & $\begin{array}{l}0.08 \\
{[1.47]}\end{array}$ & $\begin{array}{c}0.09 \\
{[1.54]}\end{array}$ & {$[0.05$} & {$[1.90]$} \\
\hline 4 & Marketing management policy $\times$ herd size & & & $\begin{array}{l}0.01^{* * *} \\
{[3.03]}\end{array}$ & $\begin{array}{l}0.01^{* * *} \\
{[3.03]}\end{array}$ & $\begin{array}{l}0.01 * * * \\
{[3.08]}\end{array}$ & $\begin{array}{l}0.01^{* * *} \\
{[3.08]}\end{array}$ \\
\hline 5 & Herd size & $\begin{array}{c}0.00 \\
{[1.09]}\end{array}$ & $\begin{array}{c}0.00 \\
{[1.14]}\end{array}$ & $\begin{array}{c}0.00 \\
{[0.46]}\end{array}$ & $\begin{array}{c}0.00 \\
{[0.46]}\end{array}$ & -0.00 & $\begin{array}{l}-0.00 \\
{[-0.35]}\end{array}$ \\
\hline 6 & $\begin{array}{l}\text { Dairy crisis }(1=\text { months after Sept. } \\
2008 ; 0=\text { months before })\end{array}$ & & $\begin{array}{l}0.11^{* * *} \\
{[3.70]}\end{array}$ & & $\begin{array}{l}-0.01 \\
{[-0.68]}\end{array}$ & & $\begin{array}{l}-0.10^{* *} \\
{[-2.57]}\end{array}$ \\
\hline 7 & Education (yr) & $\begin{array}{c}0.00 \\
{[0.16]}\end{array}$ & 0.00 & $\begin{array}{c}0.00 \\
{[0.20]}\end{array}$ & $\begin{array}{c}0.00 \\
{[0.20]}\end{array}$ & $\begin{array}{c}0.00 \\
{[0.20]}\end{array}$ & $\begin{array}{c}0.00 \\
{[0.20]}\end{array}$ \\
\hline 8 & Age (yr) & $\begin{array}{l}-0.00^{* *} \\
{[-1.99]}\end{array}$ & $\begin{array}{l}{[0.00]} \\
-0.00^{* *} \\
{[-1.99]}\end{array}$ & $-0.00^{*}$ & $-0.00^{*}$ & $-0.00^{*}$ & $-0.00^{*}$ \\
\hline 9 & Percentage of off-farm labor & $\begin{array}{l}-0.21^{* *} \\
{[-2.53]}\end{array}$ & $\begin{array}{l}-0.21^{* *} \\
{[-2.52]}\end{array}$ & $\begin{array}{l}-0.20^{* *} \\
{[-2.50]}\end{array}$ & $\begin{array}{l}-0.20^{* *} \\
{[-2.50]}\end{array}$ & {$\left[-0.20^{* *}\right.$} & $\begin{array}{l}-0.20^{* *} \\
{[-2.50]}\end{array}$ \\
\hline 10 & Asset value per capita (1,000 yuan) & $-0.04^{* * *}$ & $\begin{array}{l}-0.04^{* * *} \\
{[-3.12]}\end{array}$ & $\begin{array}{l}-0.03^{* * *} \\
{[-3.08]}\end{array}$ & $\begin{array}{l}-0.03^{* * *} \\
{[-3.08]}\end{array}$ & $\begin{array}{l}-0.03^{* * *} \\
{[-3.06]}\end{array}$ & $\begin{array}{l}-0.03^{* * *} \\
{[-3.05]}\end{array}$ \\
\hline 11 & Dairy training & $\begin{array}{c}0.08 \\
{[1.55]}\end{array}$ & $\begin{array}{c}0.08 \\
{[1.55]}\end{array}$ & $\begin{array}{c}0.07 \\
{[1.47]}\end{array}$ & $\begin{array}{c}0.07 \\
{[1.47]}\end{array}$ & $\begin{array}{c}0.07 \\
{[1.47]}\end{array}$ & $\begin{array}{c}0.07 \\
{[1.47]}\end{array}$ \\
\hline 12 & Villagers in dairy company & $\begin{array}{l}-0.05 \\
{[-0.32]}\end{array}$ & $\begin{array}{l}-0.05 \\
{[-0.33]}\end{array}$ & $\begin{array}{l}-0.07 \\
{[-0.52]}\end{array}$ & $\begin{array}{l}-0.07 \\
{[-0.52]}\end{array}$ & $\begin{array}{l}-0.07 \\
{[-0.52]}\end{array}$ & $\begin{array}{l}-0.07 \\
{[-0.52]}\end{array}$ \\
\hline 13 & Percentage of dairy households in the village & $\begin{array}{c}0.01 \\
{[1.18]}\end{array}$ & $\begin{array}{c}0.01 \\
{[1.18]}\end{array}$ & $\begin{array}{l}0.01 \\
{[1.47]}\end{array}$ & $\begin{array}{c}0.01 \\
{[1.47]}\end{array}$ & $\begin{array}{c}0.01 \\
{[1.46]}\end{array}$ & $\begin{array}{c}0.01 \\
{[1.46]}\end{array}$ \\
\hline 14 & Time trend & Yes & Yes & Yes & Yes & Yes & Yes \\
\hline 15 & Township effects & Yes & Yes & Yes & Yes & Yes & Yes \\
\hline 16 & $\mathrm{n}$ & 726 & 726 & 726 & 726 & 726 & 726 \\
\hline 17 & $\mathrm{R}^{2}$ & 0.39 & 0.40 & 0.43 & 0.43 & 0.43 & 0.44 \\
\hline
\end{tabular}

T-statistics are in brackets. The regression model that includes variables that measure both the cow hotel policy and the marketing management policy (as well as a full set of control variables) is shown in the last column of the table. In this table, we look at how farms with different herd sizes have responded to the different policies that have been implemented in response to the milk scandal. This is done by linking farm size with post-scandal production structures (cow hotel, backyard production, and quitting dairy production), given the specific policies to which farmers were exposed.

${ }^{*} P<0.10 ;{ }^{* *} P<0.05 ;{ }^{* * *} P<0.01$. 
Table 8. Results of multivariate analysis estimating the heterogeneous effects of cow hotel and marketing management policies on backyard production in Greater Beijing from August 2008 to September 2009 (ordinary least squares with township fixed effects)

Dependent variable: Backyard producer $(1=$ yes; $2=$ no $)$

\begin{tabular}{|c|c|c|c|c|c|c|c|}
\hline \multirow{2}{*}{$\begin{array}{l}\text { Independent } \\
\text { variable no. }\end{array}$} & \multirow[b]{2}{*}{ Independent variable } & & & & & & \\
\hline & & 1 & 2 & 3 & 4 & 5 & 6 \\
\hline 1 & Cow hotel policy $($ yes $=1 ;$ no $=0)$ & $\begin{array}{l}-0.18^{* * *} \\
-3.35]\end{array}$ & $\begin{array}{l}-0.10^{*} \\
{[-1.96]}\end{array}$ & & & $\begin{array}{l}-0.16^{* * *} \\
{[-3.09]}\end{array}$ & $\begin{array}{l}-0.13^{* *} \\
{[-2.56]}\end{array}$ \\
\hline 2 & Cow hotel policy $\times$ herd size & $\begin{array}{l}0.00 \\
0.02]\end{array}$ & $\begin{array}{l}0.00 \\
{[0.07]}\end{array}$ & & & $\begin{array}{c}0.00 \\
{[0.53]}\end{array}$ & $\begin{array}{l}0.00 \\
{[0.68]}\end{array}$ \\
\hline 3 & Marketing management policy $($ yes $=1 ;$ no $=0$ ) & & & {$[-0.04$} & $\begin{array}{c}0.12 \\
{[1.18]}\end{array}$ & $\begin{array}{c}0.02 \\
{[0.34]}\end{array}$ & $\begin{array}{c}0.11 \\
{[1.09]}\end{array}$ \\
\hline 4 & Marketing management policy $\times$ herd size & & & $\begin{array}{l}-0.01^{* *} \\
{[-2.46]}\end{array}$ & $-0.01^{* *}$ & $-0.01 * * *$ & $\begin{array}{l}-0.01^{* * *} \\
{[-2.62]}\end{array}$ \\
\hline 5 & Herd size & $\begin{array}{l}-0.00 \\
{[-0.13]}\end{array}$ & {$[-0.00$} & $\begin{array}{c}0.00 \\
{[1.42]}\end{array}$ & $\begin{array}{c}0.00 \\
{[1.42]}\end{array}$ & $\begin{array}{l}0.00 \\
0.66]\end{array}$ & $\begin{array}{c}0.00 \\
{[0.44]}\end{array}$ \\
\hline 6 & $\begin{array}{l}\text { Dairy crisis }(1=\text { months after Sept. } \\
2008 ; 0=\text { months before })\end{array}$ & & $\begin{array}{l}-0.13^{* * *} \\
{[-3.52]}\end{array}$ & & $\begin{array}{l}-0.19^{* * *} \\
{[-2.66]}\end{array}$ & & -0.12 \\
\hline 7 & Education (yr) & $\begin{array}{c}0.02^{*} \\
{[1.75]}\end{array}$ & $\begin{array}{l}0.02^{*} \\
{[1.75]}\end{array}$ & $\begin{array}{c}0.02^{*} \\
{[1.74]}\end{array}$ & $\begin{array}{l}0.02^{*} \\
{[1.74]}\end{array}$ & $\begin{array}{l}0.02^{*} \\
{[1.73]}\end{array}$ & $\begin{array}{c}0.02^{*} \\
{[1.73]}\end{array}$ \\
\hline 8 & Age (yr) & $\begin{array}{l}0.01^{* *} \\
{[2.52]}\end{array}$ & $\begin{array}{l}0.01^{* *} \\
{[2.52]}\end{array}$ & $\begin{array}{l}0.01^{* *} \\
{[2.27]}\end{array}$ & $\begin{array}{l}0.01^{* *} \\
{[2.27]}\end{array}$ & $\begin{array}{l}0.01^{* *} \\
{[2.26]}\end{array}$ & $\begin{array}{l}0.01^{* *} \\
{[2.26]}\end{array}$ \\
\hline 9 & Percentage of off-farm labor & $\begin{array}{l}0.08 \\
{[0.67]}\end{array}$ & $\begin{array}{l}0.08 \\
{[0.67]}\end{array}$ & $\begin{array}{c}0.07 \\
{[0.63]}\end{array}$ & $\begin{array}{c}0.07 \\
{[0.63]}\end{array}$ & $\begin{array}{c}0.07 \\
{[0.63]}\end{array}$ & $\begin{array}{c}0.07 \\
{[0.63]}\end{array}$ \\
\hline 10 & Asset value per capita (1,000 yuan) & $\begin{array}{l}0.04^{* * *} \\
{[3.16]}\end{array}$ & $\begin{array}{l}0.04^{* * *} \\
{[3.16]}\end{array}$ & $\begin{array}{l}0.04^{* * *} \\
{[3.08]}\end{array}$ & $\begin{array}{l}0.04^{* * *} \\
{[3.07]}\end{array}$ & $\begin{array}{l}0.04^{* * *} \\
{[3.06]}\end{array}$ & $\begin{array}{l}0.04^{* * *} \\
{[3.06]}\end{array}$ \\
\hline 11 & Dairy training & $\begin{array}{l}-0.06 \\
{[-1.19]}\end{array}$ & $\begin{array}{l}-0.06 \\
{[-1.19]}\end{array}$ & $\begin{array}{l}-0.06 \\
{[-1.14]}\end{array}$ & {$[-0.06$} & $\begin{array}{l}-0.06 \\
{[-1.13]}\end{array}$ & -0.06 \\
\hline 12 & Villagers in dairy company & $\begin{array}{l}-0.05 \\
{[-0.27]}\end{array}$ & $\begin{array}{l}-0.05 \\
{[-0.27]}\end{array}$ & $\begin{array}{l}-0.03 \\
{[-0.15]}\end{array}$ & $\begin{array}{l}-0.03 \\
{[-0.15]}\end{array}$ & $\begin{array}{l}-0.02 \\
{[-0.14]}\end{array}$ & $\begin{array}{c}-0.02 \\
{[-0.14]}\end{array}$ \\
\hline 13 & Percentage of dairy households in the village & $\begin{array}{r}0.00 \\
{[-0.64]}\end{array}$ & $\begin{array}{r}0.00 \\
{[-0.64]}\end{array}$ & $\begin{array}{r}0.00 \\
{[-0.82]}\end{array}$ & $\left.\begin{array}{r}0.00 \\
-0.82\end{array}\right]$ & {$\left[\begin{array}{c}0.00 \\
-0.83]\end{array}\right.$} & {$\left[\begin{array}{c}0.00 \\
-0.83]\end{array}\right.$} \\
\hline 14 & Time trend & Yes & Yes & Yes & Y $\begin{array}{ll}0.02 \\
0\end{array}$ & Yes & Yes \\
\hline 15 & Township effects & Yes & Yes & Yes & Yes & Yes & Yes \\
\hline 16 & $\mathrm{n}$ & 726 & 726 & 726 & 726 & 726 & 726 \\
\hline 17 & $\mathrm{R}^{2}$ & 0.35 & 0.36 & 0.36 & 0.37 & 0.37 & 0.37 \\
\hline
\end{tabular}

${ }^{1}$ T-statistics are in brackets. The regression model that includes variables that measure both the cow hotel policy and the marketing management policy (as well as a full set of control variables) is shown in the last column of the table. In this table, we look at how farms with different herd sizes have responded to the different policies that have been implemented in response to the milk scandal. This is done by linking farm size with post-scandal production structures (cow hotel, backyard production, and quitting dairy production), given the specific policies to which farmers were exposed

$* P<0.10 ; * * P<0.05 ; * * * P<0.01$ 


\section{Farm Size and Policy Effects}

Our results also suggest that heterogeneous effects exist. The most significant differences across households were found when we looked at the effect of the marketing management policy on the structure of dairy production. The interaction terms between the policy and herd size suggested that larger farms were more likely to shift from backyard production to cow hotels if the marketing management policy was implemented in the local township (Table 7, column 10, row 4; Table 8 , column 10, row 4). The coefficient indicates that, given this policy, by having 1 more cow in the backyard, the probability that the household would check into cow hotels rose by $1 \%$ (Table 7 , column 10 , row 4 ; Table 8 , column 10, row 4 ). The estimates are robust across all specifications. This is likely because the policy provided incentives to milk-marketing enterprises to procure from larger dairy units (complexes such as the cow hotels). When the marketing incentives were added to the profit-loss mix, it appears that larger farms benefited more than smaller farms (if they joined cow hotels). It might also be that the cost of joining a cow hotel was lower for larger farms.

Interestingly, the cow hotel policy did not show heterogeneous effects on checking into cow hotels (Table 7, row 2; see Mo et al., 2011 for robustness test). A possible explanation is that this policy was meant to move all backyard producers into cow hotels once a local cow hotel was established. Farms of different herd sizes faced the same intervention if the local township received policy directives for the cow hotel policy.

\section{CONCLUSIONS}

In the immediate aftermath of the milk scandal of 2008, China's government responded to the crisis by issuing a series of policies. The overall goal of these dairy policies was to encourage producers to organize themselves in ways that would allow for both more efficient production and more effective monitoring of quality. For example, the cow hotel policy ordered local officials to try to convince dairy farmers to check into the centralized complexes - cow hotels, which in theory, would facilitate more efficient production of more sanitary and higher-quality milk. The marketing management policy was designed to regulate and restore the supply chain and facilitate the procurement of milk from larger and more reliable dairy farms. In summary, we found that $1 \mathrm{yr}$ after the milk scandal, the dairy production structure changed substantially. Approximately onequarter $(26 \%)$ of our sample had checked in the cow hotels (increasing from $2 \%$ in August 2008). Our results demonstrated that the increase in cow hotel production could largely be attributed to the cow hotel policy and the marketing management policy. The cow hotel policy was shown to increase the probability of farmers joining a cow hotel by $11 \%$. The driving force of the change, however, seemed to be the marketing management policy, as it was shown to increase the cow hotel production by $23 \%$. When policy makers implemented the marketing management policy, larger farms in our sample were more likely to join cow hotels and less likely to maintain backyard production.

\section{ACKNOWLEDGMENTS}

We are especially grateful to Shengli Li (Center of Chinese Agricultural Policy, Institute for Geographical Sciences and Natural Resources Research, Chinese Academy of Sciences, Beijing, China) for his support and coordination during the field survey and the survey team members who contributed in collecting and cleaning data. We thank the financial support for 2 rounds of surveys in 2004 and 2009 from the National Natural Science Foundation of China (Grant No. 70903063), LICOS of KU Leuven (Methusalem Grant), the National Science Foundation for Post-Doctoral Scientists of China (Grant No. 20090450053), the 41st Scientific Research Foundation (SRF) for the Returned Overseas Chinese Scholars (ROCS), State Education Ministry of China, and the Chinese Academy of Sciences project "Global Agricultural Market Monitoring and Simulation" (Grant No. KACX1-WY-0906).

\section{REFERENCES}

Barboza, D. 2008. China's dairy farmers say they are victims. The New York Times. Accessed Sep. 24, 2009. http://www.nytimes. com/2008/10/04/world/asia/04milk.html.

Chen, F., and Y. Zhang. 2010. On the development of yangzhi xiaoqu (cow hotel) in Hongya County. Livest. Poult. Ind. 8:36-37. (in Chinese)

Chen, J. S. 2009. A worldwide food safety concern in 2008-Melaminecontaminated infant formula in China caused urinary tract stone in 290,000 children in China. Chin. Med. J. (Engl.) 122:243-244.

Chen, T.-X. 2010. Revitalization measures and the development of China's dairy industry. Food and Nutrition in China 5. (in Chinese)

China Ministry of Agriculture. 2010. Dairy statistical report of China. China Ministry of Agriculture, Beijing, China. (in Chinese)

China News. 2008a. China launched 300 million yuan as urgent compensation to dairy farmers (in Chinese: Zhongguo Caizheng Jingji Bofu Nainong Linshi Jiuzhu Butie Zijin 3 Yi Yuan; Oct. 9). Accessed Sep. 24, 2009. http://www.chinanews.com/cj/gncj/ news/2008/10-09/1406032.shtml. (in Chinese)

China News. 2008b. 102 Milk stations were shut down and another 33 were suspended in Hebei Province. Accessed Sep. 24, 2009. http://www.chinanews.com/cj/cyzh/news/2008/10-07/1402932. shtml. (in Chinese) 
Farmers' Daily. 2010. On the management of yangzhi xiaoqu (cow hotel). Accessed Apr. 4, 2011. http://www.zgny.com.cn/ifm/ tech/2010-12-17/113154.shtml. (in Chinese)

First Financial Daily. 2008. The tough nuts in claiming compensation for milk scandal's victims. Accessed Apr. 4, 2011. http://news. sina.com.cn/c/2008-11-11/020816625808.shtml. (in Chinese)

Fuller, F. H., and D. Hu. 2005. Dairy products in southwestern China: Anecdotal evidence from Kunming. In China's Agri-Food Value Chain: Opportunities and Challenges, Proc. of the Western Educational Research Activity (WERA)-101 Annual Meetings. Impact Center, Washington State University, Pullman.

Fuller, F. H., J. K. Huang, H. Ma, and S. Rozelle. 2006. Got milk? The rapid rise of China's dairy sector and its future prospects. Food Policy 31:201-215.

Gale, F., and D. Hu. 2009. Supply chain issues in China's milk adulteration incident. In Proc. The International Association of Agricultural Economists' 2009 Conference, Beijing, China. International Association of Agricultural Economists, Milwaukee, WI.

Hebei Provincial People's Congress. 2009. Baoding Municipal People's Government report on policy enforcement of the planning for yangzhi xiaoqu (cow hotel) and milk collection stations. Accessed Apr. 4, 2011. http://www.hbrd.net/InfoPage.aspx?nid=5779. (in Chinese)

Huang, J., Y. Wu, Z. Yang, S. Rozelle, J. Fabiosa, and F. Dong. 2010 Farmer participation, processing, and the rise of dairy production in Greater Beijing, P. R. China. Can. J. of Agr. Econ. 58:321-342.

Jia, X., J. Huang, L. Hao, J. F. M. Swinnen, and S. Rozelle. 2011. China's Milk Scandal, Government Policy and Production Decisions of Dairy Farmers: The Case of Greater Beijing. Center for Chinese Agricultural Policy (CCAP) Working Paper. Chinese Academy of Sciences, Beijing, China.

Li, W. 2010. On the advantages and disadvantages of yangzhi xiaoqu (cow hotel). Chinese J. Anim. Husbandry Vet. Med. 11:40-41. (in Chinese)

Liu, C., ed. 2003-2009. China Dairy Yearbook. China Agricultural Press, Beijing, China. (in Chinese)

Lu, J., Z. Tao, and C. H. L. Woo. 2009. Sanlu's Melamine-Tainted Milk Crisis in China. Harvard Business Review 1.1:24. 10.1225/ HKU837.

Ministry of Agriculture. 2011. 95\% of Beijing Dairy Farms in Yangzhi Xiaoqu (Cow Hotels). Accessed Apr. 4, 2011. http://www. feedtrade.com.cn/livestock/cattle/201103/20110301173946.html. (in Chinese)

Ministry of Finance. 2008. Notification of implementing temporary rescuring program for dairy farmers in vulnerable area. Accessed Nov. 11, 2010. http://www.mof.gov.cn/mofhome/gp/nongyesi/200902/t20090206_112232.html. (in Chinese)

Mo, D., J. Huang, X. Jia, H. Luan, S. Rozelle, and J. Swinnen. 2011. Checking into China's Cow Hotels: Have Post-Milk Scandal Policies Changed the Structure of the Dairy Sector? LICOS working paper. LICOS Centre for Institutions and Economic Performance, University of Leuven, Belgium.

National Development and Reform Commission (NDRC). 2008. Plan for Rectifying and Revitalizing China's Dairy Industry. Accessed Nov. 10, 2010. http://www.ndrc.gov.cn/zcfb/zcfbqt/2008qita/ W020081120319832687467.pdf. (in Chinese)

People's Government of Hebei Province. 2008. The bill for regulating and restructuring the dairy industry in Hebei Province. Accessed
Apr. 4, 2011. http://www.hebei.gov.cn/article/20081113/1095956. htm. (in Chinese)

People's Government of Shanxi Province. 2008. The work arrangements of the Ministry of Agriculture on subsidizing yangzhi xiaoqu (cow hotels) or large-scale farms to merge backyard farms. Accessed Apr. 4, 2011. http://www.sxny.gov.cn/Html/2009_08_03/6 4180_107100_2009_08_03_133056.html. (in Chinese)

People's Government of Zhejiang Province. 2008. Emergency notice of the People's Government of Zhejiang Province on enhancing the quality supervision of dairy products. Accessed Apr. 4, 2011. http://www.zjahv.gov.cn/html/main/zw_xztz_view/6638.html. (in Chinese)

Sohu News. 2008. Dumping their milk: Dairy farmers in Hebei are heavily affected by China's milk scandal. Accessed Sep. 24, 2009 http://business.sohu.com/20080919/n259651173.shtml. (in Chinese)

State Council of Central Committee of Communist Party of China. 2008. Strengthening agricultural base construction to promote agricultural development and income increase of farmers. Accessed Nov. 20, 2009. http://www.csh.gov.cn/article_106745.html. (in Chinese)

State Council of Central Committee of Communist Party of China. 2009. To promote the stable development of agriculture and guarantee continually increasing income of farmers. Accessed Nov. 20, 2009. http://news.xinhuanet.com/newscenter/2009-02/01/content_10746024_1.htm. (in Chinese)

State Council of the People's Republic of China. 2008. Regulation on the supervision and administration of dairy product quality and safety. Accessed Sep. 24, 2009. http://www.gov.cn/zwgk/200810/10/content_1116657.htm. (in Chinese)

Swinnen, J. F. M. 2009. Reforms, globalization, and endogenous agricultural structures. Agric. Econ. 40:719-732.

The Economic Daily. 2010. Increased profits for dairy farmers from biogas conversion. Accessed Apr. 4, 2011. http://nc.people.com. cn/GB/10938186.html. (in Chinese)

The Economist. 2008. China's baby-milk scandal: Formula for disaster. Accessed Sep. 24, 2009. http://www.economist.com/ node/12263093?story_id=E1_TNNGPDJP

Wei, Y. 2008. Is scaling up the dairy production the way out: Cases of provincial government policies in China. Chinese Journal of Veterinary Drug 10. http://www.cqvip.com/ qk/94722x/2008010/28478218.html.

Xin, H., and R. Stone. 2008. Chinese probe unmasks high-tech adulteration with melamine. Science 322:1310-1311.

Xinhua News. 2010. To achieve a $6 \%$ annual increase in farmers' income: The policy interpretation from the Ministry of Agriculture. Accessed Apr. 4, 2011. http://www.gov.cn/jrzg/2010-03/02/content_1545425.htm. (in Chinese)

Zhangjiakou News. 2009. Upgrading the dairy production in Xuanhua County. Speed up! Accessed Apr. 4, 2011. http://www.zjknews. com/read.asp?newsid $=128711$. (in Chinese)

Zhongshan News. 2009. A review of the 2008 milk scandal. Accessed Apr. 4, 2011. http://www.zsnews.cn/Backup/2009/03/11/1054532. shtml. (in Chinese)

Zhou, Z., W. Tian, and J. Zhou. 2002. The emerging dairy economy in China: Production, consumption and trade prospects. Australas. Agribus. Rev. 10:Paper 8. 